LSP International Journal, Vol. 6, Issue 2, 2019, 45-59

(C) Universiti Teknologi Malaysia

E-ISSN 2601-002X

DOI: https://doi.org/10.11113/lspi.v6n2.91

\title{
Technical Report Writing in Engineering Studies
}

\author{
Teh Zanariah Mohd. Raus, Mariana Yusoff \& B. Subatira \\ Department of Languages, Centre for Languages and Human Development, Universiti Teknikal Malaysia \\ Melaka (UTeM)
}

Submitted: 1/08/2019. Revised edition: 29/10/2019. Accepted: 31/10/2019. Published online: 05/12/2019

\begin{abstract}
Technical reports are very important in engineering domain, as they are the main genre in reporting and communicating information among members in an engineering community. In addition, the engineering students need to be competent in writing technical report because an effective technical report will determine them in being hired and being promoted in their future career. A set of questionnaires was distributed to sixty undergraduates from the Faculty of Electronics and Computer Engineering, Universiti Teknikal Malaysia Melaka (UTeM) to seek the engineering students' knowledge on technical report writing. Additionally, samples of students' technical report writing were analysed by using the Genre Analysis approach for technical report writing (Cheung \& Lai, 1997) to identify the Move Structure involved in writing technical report. The findings indicated that the students have already obtained the knowledge of generic structure in report genre and five Move Structure were identified in technical report writing. This study has recommended the ESP practitioners to use the genre-based approach in teaching technical report writing to the students as it allows them to have better understanding on how the technical reports were structured and organised.
\end{abstract}

Keywords: Genre Analysis, English for Academic Purposes, Technical Report, Move Structure

\section{INTRODUCTION}

The teaching of technical writing at tertiary level education is important since it provides the students with the foundation skills in writing various types of technical documents such as business letters, memos, resumes, proposals, reports and manuals. A good technical writing communicates ideas, data as well as conclusion efficiently and clearly therefore an understanding of technical writing principles will benefit a student who intends to go into any field of work. In engineering domain, report writing is part of every engineer's career thus the major focus of technical writing is preparing the engineering students with the skills of writing technical report. A quality report writing is an indication of the engineer's written work where the promotion may actually depend on it.

*Correspondence to: Teh Zanariah Mohd. Raus (email: tehzanariah@utem.edu.my) 
Government and industry professionals definitely expect the engineers to write substantial technical reports, proposals, and other documents that are carefully planned, organised and effective in order to be competent in their jobs. Marshall (1991) states that explicit knowledge of genres including the knowledge of their rhetorical structures will enable teachers and students to be clear about the learning required (p.3). With regard to English for Science and Technology (EST) students, Selinker et al. (1976) point out that often it is not the lack of the vocabulary but the lack of knowledge of the appropriate formal schemata which leads to poor comprehension. Thus, to prepare the engineering students for professional careers and to fulfill their future employers' demands, English for Specific Purposes (ESP) practitioners involved in the teaching of technical report writing need to train the students in understanding the strategy of designing and structuring their reports (Loh, Lee \& Lai, 2015).

Although reports maybe classified as an investigative and analytical genres as well as descriptive in terms of generic organisational structure of design and construction process, all forms of technical reports are derivatives of a basic structural framework. Reports usually follow a basic framework (or schema) with an introduction, method, results and conclusion. A genre-based approach is highly recommended to be used in the teaching of technical report writing as it aims to help students in mastering the conventional structure of the different sections in technical reports. Using genre as the analytical tool for an investigation of engineering discourse would reveal how technical reports are structured. The genre-based approach is not meant only to get students interested in specific tasks but also to take them through the dynamics of reporting on a range of engineering activities, processes and products. Analysis of the Move Structure in the genre of technical reports can conform to certain standard practices within the boundaries of the genre. It means that genre analysis is useful as a means of studying written discourse such as technical reports in engineering studies. Hence, the specific objectives of this study are:

1. To seek the engineering students' knowledge on technical report writing.

2. To identify the Move Structure involved in technical report writing.

\section{English for Academic Purposes}

Dudley-Evans \& St. John (1998) mention that English for Specific Purposes (ESP) has traditionally been divided into two main areas which are English for Academic Purposes (EAP) and English for Occupational Purposes (EOP). The primary purpose of all EAP courses at tertiary level is to equip non-native speakers with the language and study skills needed so that they may follow their field of academic study successfully. Apart from that, EAP also seeks to provide insights into the structures and meanings of academic texts of which one of the productive areas in EAP is genre analysis.

\section{Genre Analysis in English for Academic Purposes}

Since EAP is often divided according to discipline or professional area, the awareness and the ability to use different genres are needed as different domains have different communicative purposes. The 
engineering students, for example, have to read articles and manuals, prepare proposals and write technical reports. These are EAP needs that have to be mastered by them in order to function effectively in the discourse community of engineering. Hence, genre analysis is extremely crucial to EAP students since the focus of genre analysis is on the regularities of structure that distinguish one type of text from another at both written and spoken texts.

Nowadays, the concept of discourse community is an important principle in EAP as it sets agenda to focus on revealing the genres and communicative conventions of academic disciplines. The knowledge then is used to assist the students to critique and participate in such communities (Hyland \& Hamp-Lyons, 2002, p.6).

\section{Definitions of Technical Report}

Technical reports are defined as "consisting of factual and technical information in nature where the documents are written for a defined audience and a defined purpose" (Shelton, 1994:1). In addition, Krishnan et al. (2003) state that technical report is a "structured presentation of data or information gathered from research, experiment or investigation and prepared for a selected group of audience, at the request of a supervisory authority, to fulfil specific information needs of the audience" (p.1).

\section{Move Structure in Technical Reports}

The concept of 'Move Structure Analysis' can offer help on how the genre may be successfully written. Traditional genre analysis proposes 'moves' or functional components as basic elements of a genre (Swales, 1990:117) and it is argued that such moves can be taught to novice writer of a particular genre (Bhatia, 1993; Dudley-Evans, 1995). In ESP, a number of researchers have analysed the move structure in various written genres such as in research article (Swales, 1981 \& 1990), dissertations (Hopkins \& Dudley-Evans, 1988) and grant proposals (Connor, 2000; Connor \& Mauranen, 1999). Unfortunately, very little published research has examined the move structure of technical report genres in engineering studies except for previous studies conducted in experimental research report (Weissberg \& Buker, 1990).

In engineering study, Cheung \& Lai (1997) state that "at the macro structure of writing technical reports, students struggle with the organisation of the classic Introduction-Method-ResultsDiscussion-Conclusion of technical report genre" (p.31). For example, engineering students have to determine where information such as the Background, Scope, Problem Statement, Literature Review, Method, Conclusion, etc. should be placed in the report writing. The moves mentioned above are also known as 'content schemata' (Carell, 1983) which deal with general background knowledge of the genre. On the other hand, Krishnan et al. (2003) identified a complete formal technical report as usually consisting of three moves which are prefatory, main and supplementary sections (p.7).

In order to overcome the structure deficiencies in writing technical report among engineering students, it is believed that a genre-based analytical framework is effective to help students in mastering the conventions and move structure in writing technical report in order to identify the misplaced content in technical report writing (Cheung \& Lai, 1997:32) as shown in Figure 1 below. 


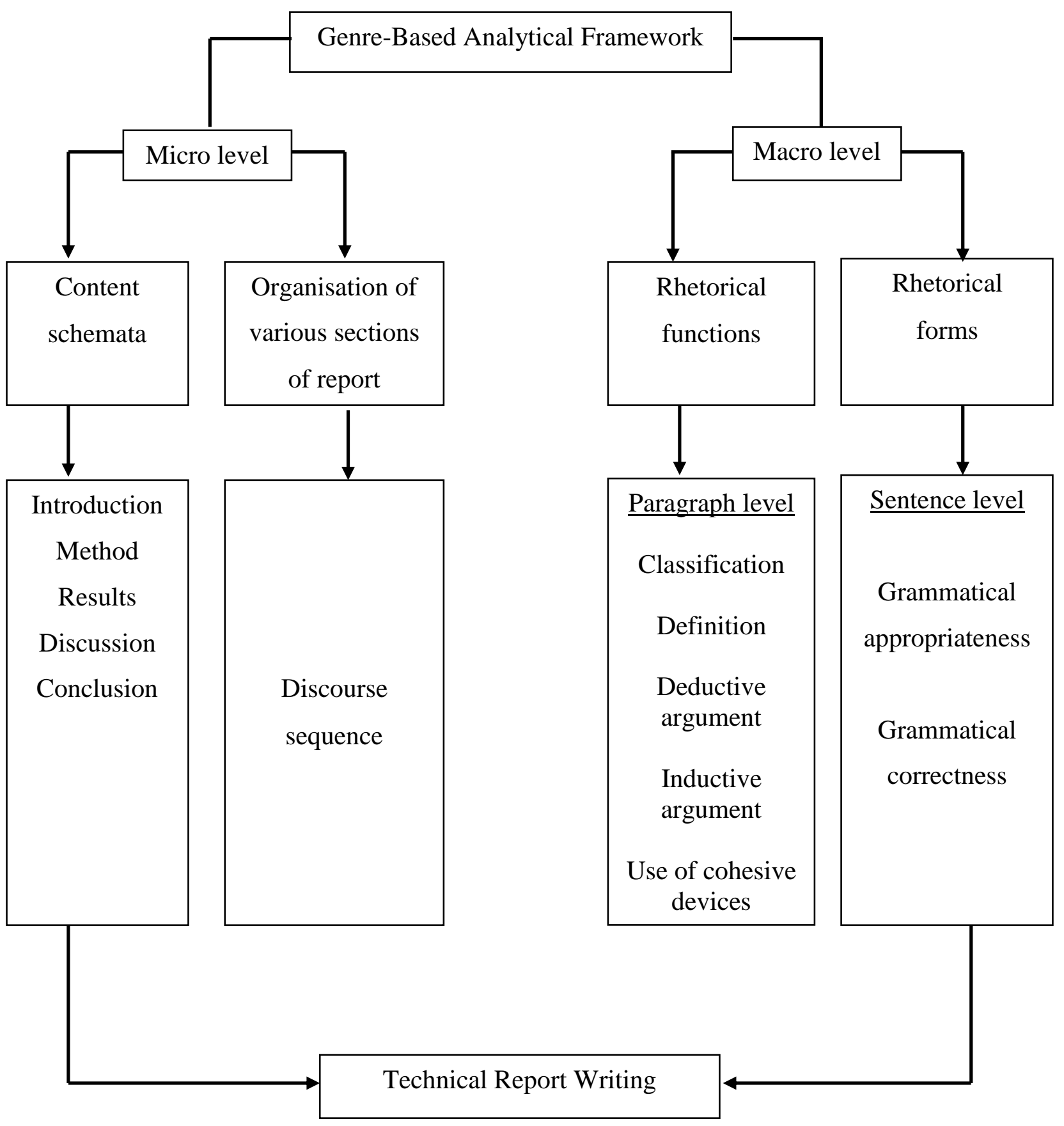

Figure 1 Genre analysis approach for technical report writing (Cheung \& Lai, 1997) 


\section{METHODOLOGY}

\section{Sample of the Study}

The sample of this study was sixty undergraduates of second year students who are pursuing their studies in Bachelor of Electronics and Computer Engineering at the Faculty of Electronics and Computer Engineering, Universiti Teknikal Malaysia Melaka (UTeM). They have also taken the Technical Communication course and have been exposed to technical report writing.

\section{Data Collection}

\section{Questionnaires}

A set of questionnaires was developed by utilising the Genre Analysis Approach for Technical Report Writing (Cheung \& Lai, 1997) to seek the students' knowledge on writing technical report. The questionnaire was structured using both open-ended and close-ended questions. It was distributed to sixty undergraduate students from Faculty of Electronics and Computer Engineering, UTeM. The questionnaire was administered during week 15 of the semester and was conducted under the supervision of the researcher.

\section{Students' Technical Reports Writing}

The authentic samples of students' technical report writing were analysed in order to identify the Move Structure involved in writing technical reports for engineering studies. The writing samples were written by the students as their group project for Technical Communication course. They were asked to write a technical report based on a topic that is related to their field of studies.

\section{Data Analysis}

The findings obtained from the questionnaires were analysed in percentages and presented in tables. The Move Structure involved in the students' writing samples of technical reports was analysed using the Genre Analysis Approach for Technical Report Writing (Cheung \& Lai, 1997).

\section{Findings}

Questionnaires

1. Level of Proficiency in Technical Report

The findings of the respondents' proficiency in technical report writing are shown in Table 1 below. It is found that majority of the respondents (55\%) rated themselves as average in writing technical reports. Meanwhile, 30\% of them rated themselves as good in writing technical reports. Only $6.7 \%$ 
rated themselves as excellent in writing technical reports. On the other hand, $5 \%$ of the respondents rated themselves as weak and $3 \%$ of them rated themselves as very weak in writing technical reports.

Table 1 Level of proficiency in technical report writing

\begin{tabular}{|c|c|c|}
\hline Level of Proficiency & Frequency & Percentage (\%) \\
\hline Excellent & 4 & 6.7 \\
\hline Good & 18 & 30 \\
\hline Average & 33 & 55 \\
\hline Weak & 3 & 5 \\
\hline Very weak & 2 & 3.3 \\
\hline
\end{tabular}

\section{Importance in Technical Report Writing}

Table 2 below shows the degree of importance in technical report writing based on the respondents' field of specialisation. Most of the respondents (61.7\%) regarded technical report writing as necessary in their studies while $31.7 \%$ of them regarded technical report writing as highly necessary. Only $6.6 \%$ of the respondents regarded technical report writing as undecided. None of the respondents regarded technical report writing as unnecessary and highly unnecessary.

Table 2 The importance in technical report writing

\begin{tabular}{|c|c|c|}
\hline Degree of Importance & Frequency & Percentage (\%) \\
\hline Highly necessary & 19 & 31.7 \\
\hline Necessary & 37 & 61.7 \\
\hline Undecided & 4 & 6.6 \\
\hline Unnecessary & 0 & 0 \\
\hline Highly unnecessary & 0 & 0 \\
\hline
\end{tabular}

\section{Types of Technical Report}

As shown in Table 3 below, lab report (95\%) and project report (93.3\%) were the most required reports for the respondents to write in electrical and computing engineering programme. Meanwhile, $68.3 \%$ of the respondents stated that industrial training report was also required in their studies. Research report (45\%) was also considered as required in their specialisation. Apart from that, $31.7 \%$ of the respondents indicated that the progress report as required in their studies, while $11.7 \%$ stated that other types of report are also required such as daily report. Only $8.3 \%$ of the respondents considered site report as required in their studies. 
Table 3 Types of technical report

\begin{tabular}{|c|c|c|}
\hline Types of Technical Report & Frequency & Percentage (\%) \\
\hline Lab Report & 57 & 95 \\
\hline Site Report & 5 & 8.3 \\
\hline Project Report & 56 & 93.3 \\
\hline Progress Report & 19 & 31.7 \\
\hline Industrial Training Report & 41 & 68.3 \\
\hline Research Report & 27 & 45 \\
\hline Others & 7 & 11.7 \\
\hline
\end{tabular}

\section{Parts of Technical Report}

Table 4 below shows the parts of technical report that the students have included while writing their reports. $91.7 \%$ of the respondents have included the title page for their technical reports. Meanwhile, $80 \%$ of them have written the abstract and acknowledgements for the reports. Besides that, $90 \%$ of the respondents have included the table of contents in their reports. The list of figures $(85 \%)$ and the list of tables $(86.7 \%)$ have also been included by them. Majority of the respondents $(98.3 \%)$ have written the main section (content) of the technical reports. Most of the respondents have included the references $(91.7 \%)$ and appendices $(81.7 \%)$ in writing technical report.

Table 4 Parts of technical report

\begin{tabular}{|l|l|l|}
\hline \multicolumn{1}{|c|}{ Part of Technical Report } & \multicolumn{1}{c|}{ Frequency } & \multicolumn{1}{c|}{ Percentage (\%) } \\
\hline Title Page & 55 & 91.7 \\
\hline Abstract & 48 & 80 \\
\hline Acknowledgements & 45 & 75 \\
\hline Table of Contents & 54 & 90 \\
\hline List of Figures & 51 & 85 \\
\hline List of Tables & 52 & 86.7 \\
\hline Main Section & 59 & 98.3 \\
\hline References & 55 & 91.7 \\
\hline Appendices & 49 & 81.7 \\
\hline
\end{tabular}

\section{Ways of Organising Technical Report}

Table 5 below shows the findings of the respondents' preferences in writing technical reports. $90 \%$ of the respondents preferred to follow the format taught by their lecturer while $85 \%$ of them preferred to use reference book in writing technical reports. On the other hand, $41.7 \%$ of the respondents preferred to use their own style in writing reports. $33.3 \%$ of them preferred to ask their friends in helping them 
writing the reports. Only $11.7 \%$ preferred to use other methods such as referring to Internet and copying the previous technical reports done by their seniors and peers.

Table 5 Ways of organising technical report

\begin{tabular}{|l|l|l|}
\hline \multicolumn{1}{|c|}{ Ways of Organising } & Frequency & \multicolumn{1}{c|}{ Percentage (\%) } \\
\hline Use reference book & 51 & 85 \\
\hline Ask friends for help & 20 & 33.3 \\
\hline Write using your own style & 25 & 41.7 \\
\hline Follow the format taught by lecturer & 54 & 90 \\
\hline Other methods & 7 & 11.7 \\
\hline
\end{tabular}

\section{Comments on Technical Report Writing}

Table 6 below shows the student's comments on technical report writing. Only $45 \%$ of the respondents have written their comments on the questionnaire form.

Table 6 Comments on technical report writing

\begin{tabular}{|c|l|}
\hline Respondent & \multicolumn{1}{|c|}{ Comment } \\
\hline 1 & $\begin{array}{l}\text { Each technical report must follow their own format based on their } \\
\text { company/faculty. }\end{array}$ \\
\hline 2 & Complicated to do technical report. \\
\hline 3 & $\begin{array}{l}\text { Last sem, I was taking technical report I, from what I observed, the technical } \\
\text { report requires high grammar and writing skill compared to technical content } \\
\text { of itself. So, why not if technical reports just focus on the important things } \\
\text { instead on focusing of its grammar. }\end{array}$ \\
\hline 4 & $\begin{array}{l}\text { Technical report is essential for engineering students because it is systematic } \\
\text { and highly organized. }\end{array}$ \\
\hline 5 & $\begin{array}{l}\text { It is very important to know and understand about writing technical report } \\
\text { because it shows the progress of a project or work that have been done } \\
\text { systematically and respectively. }\end{array}$ \\
\hline 6 & $\begin{array}{l}\text { This is a very important subject for an engineer because it teaches us how to } \\
\text { make a technical report. }\end{array}$ \\
\hline 8 & Technical Report is very important in preparation for the meeting room. \\
\hline 9 & $\begin{array}{l}\text { Students follow the format taught by lecturer and using reference book. } \\
\text { Writing report is necessary in my field of study. Almost every week I have to } \\
\text { by lecturer. Somehow I do not prefer to use the format just like in technical } \\
\text { report writing. }\end{array}$ \\
\hline 10 & $\begin{array}{l}\text { In writing the technical report, I must follow the format given by the } \\
\text { lecturer. }\end{array}$ \\
\hline
\end{tabular}




\begin{tabular}{|l|l|}
\hline Respondent & \multicolumn{1}{|c|}{ Comment } \\
\hline 11 & $\begin{array}{l}\text { I don't like writing technical report. It is so difficult and got many steps to } \\
\text { finish it. }\end{array}$ \\
\hline 12 & Writing report is so hard and difficult. \\
\hline 13 & $\begin{array}{l}\text { Learn many on how to make a resume properly for future of ourself. Can } \\
\text { repair our English (fundamental) on writing a resume for working finding and } \\
\text { also for LI semester. }\end{array}$ \\
\hline 14 & $\begin{array}{l}\text { Learn more to write a technical report. Necessary to present our idea about } \\
\text { the project. }\end{array}$ \\
\hline 15 & Necessary for engineering students. \\
\hline 16 & Important knowledge for student. \\
\hline 17 & $\begin{array}{l}\text { It's very useful to refer technical report after done any lab or research. Good } \\
\text { writing skills can be improved if write more. The way to success is become } \\
\text { near and near. }\end{array}$ \\
\hline 18 & Always refer to freelance reports for the best way to improve your report. \\
\hline 19 & $\begin{array}{l}\text { Learn much about technical report. Know to write technical report very } \\
\text { good. }\end{array}$ \\
\hline 20 & In writing report must follow their own format. \\
\hline 21 & $\begin{array}{l}\text { Writing technical report must be accurat and sharp to point. It not an essay } \\
\text { which use the diffucul or flower words. As a Engineer, the technical report is a } \\
\text { part of job. }\end{array}$ \\
\hline 22 & If necessary, technical report should be more easier. \\
\hline 23 & Technical report train us to be professional report writer. \\
\hline 24 & Having to learn first before being able to write it. \\
\hline Must understand the experiment before write a technical report. \\
\hline 26 & $\begin{array}{l}\text { Technical report should be taught from the very first year of studying in } \\
\text { UTeM as it is an essence in the future career of students in UTeM. }\end{array}$ \\
\hline
\end{tabular}

\section{Students' Writing Samples}

\section{Move Structure in Technical Reports}

The Move Structure analysis of technical report writing in engineering studies was analysed through the genre analysis approach for technical report writing (Cheung \& Lai, 1997). By using the authentic samples of students' technical report writing, the findings of this study were focused on the Move Structure involved in the main content of the technical reports. As mentioned by Cheung \& Lai (1997), the main content of the technical reports were the Introduction, Method, Results, Discussion and Conclusion. For the purpose of this paper, only one sample of technical report writing is explained in details. 


\section{Move 1 - Introduction Section}

Based on the sample entitled 'Upgrading the Specification of Wireless Printer', it was found that there are four steps: the background of the study, the objectives of the study, the scope of the study and the organisation of the report were given.

\section{Step 1 -Background of the Study}

The background of the study was written by providing the definition of wireless in order to make the reader understand the term used throughout the report. For instance, 'According to Baruch (2008), wireless is defined as "telecommunications in which electromagnetic waves (rather than some form of wire) carry the signal over part of the entire communication path. Some monitoring devices, such as intrusion alarms, employ acoustic wave of frequencies above the range of human hearing; these also sometimes classified as wireless" (p. 34).

The paragraph was then developed by stating the weaknesses of the existing cable printer. It was written as 'There are several weaknesses associated by using the normal cable printer. For example, when there are several computers need to access to the printer, port hub device is needed in order t make network to the host computer.'

Finally, this section ended with the advantages of the upgraded specification of the wireless printer such as 'The upgraded wireless printer gives benefit to the network since the old wired set ups depend on the host computer can just be turned off. The wireless printer are innovate perfectly to overcome all the cable printer problems as it can access by computer or laptop from elsewhere and does not need computer host to install the printer driver. Thus, the transfer of data is faster and easy to be done.'

Step 2 - Objectives of the Study

The objectives of the report need to be stated clearly as it determines the aims or targets of the research. The main objectives of the study were written as 'To upgrade the specification of wireless printer' and 'To make printing process goes easy and more efficiently'.

\section{Step 3 -Scope of the Study}

The scope section is an elaboration of the objectives section, putting a kind of frame around the research so that the reader is clear about what is included and not included in the study. Based on the writing sample, it was stated as 'Our research project focus primary on searching information regarding the specification of the wireless printer and also the details in upgrading the printer. Other aspects such as the production and marketing of the wireless printer are not covered in this report.' 
Step 4-Organisation of the Report

This organisation section is a development of the scope - a sort of preview of the report ahead. It states where different information can be found within the report. For instance, 'The organisation of this report as follows: Chapter 1 discusses about the introduction of the wireless printer. Chapter 2 describes mainly the methods, materials and procedures of the research. Chapter 3 presents the results and discussion of the project. The conclusion and recommendations are described in Chapter 4.'

\section{Move 2 - Methodology Section}

The importance of Move 2 in the report was to inform the reader on how the study was conducted. This section contains the information on the method used, the materials and the procedures involved in conducting the study.

$\underline{\text { Step } 1-\text { Method }}$

Based on the writing sample, the methods used in the study were written as 'The methods that we used for data collection are questionnaire and internet articles. We search for information about the wireless network and the ways to implement it in the printer to make it becomes a wireless device. On the other hand, an analysis for the wireless printer is done through questionnaire.'

\section{$\underline{\text { Step } 2 \text { - Materials }}$}

This section provides the reader with information on the equipment or materials used in the study. It was written as 'The materials that have been used in the upgrading process are printer, computer internet network, wireless router, printer adapter, Bluetooth connection and WPA2 security system software.'

\section{$\underline{\text { Step } 3 \text { - Procedures }}$}

This section explains the process involved and how it works. Based on the sample entitled 'Upgrading the Specification of Wireless Printer', the students have written the procedures based on two different methods mentioned earlier in the method section. For instance, 'In the process of finding the information through the internet article, at first we have a fully understanding on our topic. Then, we identified the keywords from the title. Next, we went to the Google website and used 'advanced search' to find for the relevant information. We were trying to select the facts in the articles format so that the name of the author and the retrieval date were provided. Finally, we have selected the top 10 articles which we think quite useful and relevant to our topic. For the questionnaire method, we have first selected 25 UTeM students to give their opinion on wireless printer. The survey was then distributed at the faculty.' 


\section{Move 3 - Results and Discussion Section}

This section explains in detail the findings made of the report. From the students' writing sample, it is found that the results included the information and data gathered from both methods used in the study. The information obtained from the internet articles were written as below:

'We have upgraded the printer so that it is able to supports Wi-Fi (802.11x) or Bluetooth. The purpose of the high Wi-Fi receiver capability is to ensure that the wireless printer is always connected to the internet even though the internet signal is weak at certain times.... Therefore, we have to upgrade the wireless printer with the specification of Bluetooth in order to print it in short distance.'

'We have also improved the security of wireless printing by using the Wi-Fi Protected Access 2 (WPA2) security system. With the WPA2 security standard built in our printer, it adds extra security mechanism to hinder "drive-by-intruder" scenarios. Besides, the firewall software is installed in the printer to protect against the virus.'

'The mobility of the wireless printer was upgraded for true portability. This upgrading includes the power source, durability, size and the weight of the printer....So, this wireless printer will be supplied with the lithium-ion battery.'

'The speed of the wireless printing was upgraded as well. The speed of wireless networking start from 11 Mbps with wireless B, followed by G with 54Mbps speed and latest one is 320Mbps speed of wireless $N$. Our product comes with wireless $N$ builtin.'

On the other hand, data gathered from the questionnaire as been stated as below:

'It was found that majority of the UTeM students (63\%) felt that the coverage of the wireless printer needs to be upgraded.'

'It was found that $63 \%$ of the students thought that the wireless printers designed today do not satisfy their need. They expect the printing process to have higher speed, better coverage and higher security.'

It was found that 15 out of 25 students felt that the upgraded wireless printer is excellent. 


\section{Move 4 - Conclusion and Recommendations Section}

This final section of the students' writing sample has provided the overall conclusion and recommendation of the study based on the results obtained. In this section, the information was arranged using the numbering system for clear explanation and better understanding. It was written as the following:

\section{Step 1 -Justification of Objectives}

The study was undertaken with the aim of upgrading the specification of the wireless printer and making printing process goes easy.

Step 2 -Review of Scope/Method

The objectives were achieved through internet sources and distributed questionnaires among the UTeM students.

\section{$\underline{\text { Step } 3 \text {-Review of Significant Findings }}$}

One of the main findings in this study is to upgrade the specification of wireless printer that includes the speed, coverage, mobility, and security.

Step 4 -Explanation of the significance Findings

The upgrading process was done due to the existing problems related to the printing process which makes the printing process become inconvenient.

\section{Step 5 -Limitation of the Study}

However, the research did not involve all the UTeM students in the survey.

\section{Step 6 -Implications of the Study}

The research is important because the upgrading of the printer benefits the students in many aspects such as easy printing and save money.

\section{$\underline{\text { Step } 7 \text {-Recommendations for Future Studies }}$}

It is recommended that future studies on this topic to substantiate the data by involving not only the students but also the user of the printer in different sectors. 


\section{CONCLUSION}

The findings obtained from questionnaire show that the students of Bachelor in Electronics and Computer Engineering, UTeM have already obtained the knowledge of generic structure in report genre. Majority of the students are at the average level of proficiency in writing technical report. This shows that their knowledge on technical report writing is crucial in structuring the technical reports. Based on the degree of importance in technical report writing, it can be said that technical report writing is necessary in engineering studies. Lab reports and project reports are the most required reports for the students to write in electrical and computing engineering programme. In term of the parts of technical report, it seems that technical reports are highly conventional because they required for well-structured organisation of the reports. In order to organise and structure their report writing, it was found that all students who involved in this study preferred to follow the format taught by their lecturer.

The students' writing sample of technical report used in conducting this study have shown that there are five Move Structure involved in technical report writing namely Move 1-Intoduction, Move 2-Methods, Move 3-Results, Move 4-Discussion and Move 5-Conclusion. From the findings, it is clearly shown that the Move Structure obtained in this study is parallel with the previous research conducted by Cheung \& Lai (1997).

\section{RECOMMENDATIONS}

It is recommended that future research in genre analysis should emphasis more on the generic structure of technical reports itself. Very few of the previous research have focused on the Move Structure in technical report writing compared to the Move Structure analysis done in business letters, medical reports, legal texts and introduction of research articles. It is also suggested that genre-based approach should be used in teaching the students of specific genres involved in their target disciplines as it is able to help the students in understanding how a text is structured and organised. Thus, by using the genre-based approach in teaching the ESP students, structural problems in technical report writing could be remedied.

\section{REFERENCES}

Bhatia, V. K. 1993. Analysing Genre: Language Use in Professional Settings. London: Longman.

Carell, P. L. 1983. Some Issues in Studying the Role of Schemata or Background Knowledge in Second Language Comprehension. Reading in Foreign Language. 1: 81-92.

Cheung, D. \& Lai, P. C. 1997. The Genre Analysis Approach to Technical Report Writing: A Template or Analytical Framework? ESP Malaysia. 5(1): 29-38. 
Connor, U. \& Mauranen, A. 1999. Linguistics Analysis of Grant Proposals: European Union Research Grants. English for Specific Purposes. 18: 47-62.

Connor, U. 2000. Variation in Rhetorical Moves in Grant Proposals of US Humanists and Scientists. Text. 20: 1-28.

Dudley-Evans, T. \& St. John, M. J. 1998. Development in ESP: A Multidisciplinary Approach. New York: Cambridge University Press.

Dudley-Evans, T. 1995. Common-core and Specific Approaches to the Teaching of Academic Writing. In Belcher, D. \& Braine, G. (Eds.). Academic Writing in a Second Language: Essays on Research and Pedagogy. New Jersey: Ablex Publishing Corporation. 293-312.

Hopkins, A. \& Dudley-Evans, T. 1998. A Genre-based Investigation of the Discussion Sections in Articles and Dissertations. English for Specific Purposes. 7: 113-121.

Hyland, K. \& Hamp-Lyons, L. 2002. EAP: Issues and Directions. Journal of English for Academic Purposes. 1: 1-12.

Lakshmy Anantha Krishan, Rowena Jong, Sujata S. Kathpalia \& Tam Moh Kim. 2003. Engineering Tour Report: From Start to Finish. Singapore: Prentice Hall.

Loh Yoke Len, Lee Kean Wah \& Lai Yew Meng. 2015. Embedded Moves in Abstracts of Research Articles in the Field of International Studies and Their Linguistic Realisations. LSP International Journal. 2(1): 95-109.

Marshall, S. 1991. A Genre-based Approach to the Teaching of Report Writing. English for Specific Purposes. 10: 3-13.

Selinker, L., Todd, R.M. \& Trimble, L. 1976. Presuppositional Rhetorical Information in EST Discourse. TESOL Quarterly. 10(3): 120-129.

Shelton, J. H. 1994. Handbook for Technical Writing. Illinois: NTC Business Books.

Swales, J. M. 1981. Aspects of Article Introductions. Birmingham: University of Aston.

Swales, J. M. 1990. Genre Analysis: English in Academic and Research Settings. New York: Cambridge University Press.

Weissberg, R. \& Buker, S. 1990. Writing Up Research: Experimental Research Report Writing for Students of English. London: Prentice-Hall. 